\title{
IDENTIFICATION OF NUTRIENT COMPOSITION OF SOME ISOLATED MICROALGAE FROM MANGROVES OF XUAN THUY NATIONAL PARK
}

\author{
Le Xuan Tuan*, Tran Thi Minh Hang \\ Hanoi University of Natural Resources and Environment
}

\begin{abstract}
Microalgae species, such as Amphiprora alata, Chaetoceros muelleri, Nannochloropsis oculata, Navicula tuscula and Chlorella vulgaris from mangrove area of Xuan Thuy National Park are usually used as food sources for fishes, shrimps and bivalves and very environment friendly. The samples of these microalgae were enriched, isolated and purified in F/2 medium with salinity of $20 \%$. The purified colonies were cultured in media with different salinity in 14 days to find out the most optimal medium for the best growth as well as the stage yielding maximum living mass. These microalgae were then cultured in their optimal media at salinity of $25 \%$ until they reached their maximum living mass stage. They were cultivated and analyzed of their fatty acid, protein carbonhydrate components and percentages. The research has identified 24 fatty acids in 5 phytoplankton species. Unsaturated fatty acids components of Chaetoceros muelleri, Nannochloropsis oculata are the highest (76,35\% and 71,17\%), and fatty acid components of are medium Chlorella vulgaris and Amphiprora alata $59,24 \%$ and $52,21 \%$ ), meanwhile, Navicula tuscula has $29.56 \%$ of unsaturated fatty acids. Amphiprora alata and Chlorella vulgaris have protein content of $8.1 \mathrm{~g}$ per $100 \mathrm{~g}$ dry weight and $4.44 \mathrm{~g}$ per $100 \mathrm{~g}$ dry weight accordingly. Carbohydrate content of Nannochloropsis oculata and Navicula tuscula are $11.8 \mathrm{~g}$ per $100 \mathrm{~g}$ dry weight and $5.47 \mathrm{~g}$ per $100 \mathrm{~g}$ dry weight, respectively.
\end{abstract}

Keywords: Microalgae, Mangroves, Nannochloropsis oculata, Navicula tuscula, fatty acid, protein, carbohydrate.

Citation: Le Xuan Tuan, Tran Thi Minh Hang, 2018. Identification of nutrient composition of some isolated microalgae from mangroves of Xuan Thuy National Park. Academia Journal of Biology, 40(4): 45-55. https://doi.org/10.15625/2615-9023/v40n4.9369.

*Corresponding author email: 1xtuan@ @unre.edu.vn

Received 23 March 2017, accepted 20 May 2018

\section{INTRODUCTION}

Mangroves of Xuan Thuy National Park (NP) plays a very important role due to their functions and services. Within the mangrove ecosystem, microorganisms, especially microalgae, are very important because they are essential in material and energy metabolism as well as have rapid growth creating huge biomass. They produce several chemical components, such as proteins, lipids, fatty acids, carbohydrates and pigments as well as silica, carbonate calcium and pectin which are part of bone composition (Ohse et al., 2015). According to Muller-Feuga et al. (2003), overall world production of these microalga-consuming species reached $12 \times$ $106 \mathrm{t}$ in 1999, i.e. $28 \%$ of world aquacultural production (FAO: Shatz, 2000). Highly unsaturated fatty acids like EPA (eicosapentaenoic acid), DHA (docosahexaenoic acid) and AA (arachi- donic 
acid) are essential in the development, growth, and physiological activities of aquaculture organisms. Microalgae are important main sources of EPA and DHA. (Ronquillo et al., 2012). The main microalga-consuming aquaculture groups include filtering mollusks, shrimps and small larva fish. Hatcheries in which larval and juvenile production depends on cultured microalgae are assuming an increasingly important role; and the survival and growth of various marine fish larvae are improved by the addition of microalgae.

In marine hatcheries, Amphiprora alata, Chaetoceros muelleri, Chlorella vulgaris, Nannochloropsis oculata and Navicula tuscula are common microalgae used as food source for shrimp and mollusk (Shirota, 1996; Truong Ngoc An, 1993; Ben-Amotz et al., 1987; Parrish et al., 1998) as well as to maintain water quality (Le Xuan Tuan et al., 2005, 2008). There are differences in lipid composition of microalgae cultures including fatty acid profiles between different species and within the same species (Malakootian et al., 2016). The studies on fatty acids of some strains of microalgae have been implemented (Ronquillo et al., 2012, Liang et al., 2004, Hoa et al., 2010). Still, not much studies on the nutrient content included fatty acid composition of microalgae have been carried out in mangrove area of Vietnam. Thus, present study aims to identify nutrient content of microalgae from mangroves of Xuan Thuy $\mathrm{NP}$ in order to contribute in improving quality of alga-based food source cultivated for coastal aquaculture.

\section{MATERIALS AND METHODS}

The experiments were conducted in Laboratory at Department of Algae Technology, Institute of Microorganisms and Biotechnology, Faculty of Biological Sciences, Hanoi University of Education. The studied microalgae included Amphiprora alata, Chaetoceros muelleri, Chlorella vulgaris, Nannochloropsis oculata, and Navicula tuscula. The experimental design comprised randomised samples with three repetitions.

\section{Material, enrichment and isolation}

Microalgae samples were collected, enriched and briefly morpholocial identified using Olympus photomicroscope. After that, samples were then subdivied. $100 \mu \mathrm{l}$ of sample were driped on petri dish containing culture medium, after culturing for 5-7 days at room temperature with light intensity of 10,000 luxat light/dark cycle of 10-14 hours, colonies developed on the petri dish. These colonies were then separeated and examined using Olympus stereo microscope. Purified colonies were then cultured into slant and kept at $4^{\circ} \mathrm{C}$ for further step of experiment.

\section{Growth analysis of microalgae}

Pure microalgae strains of Amphiprora alata, Chaetoceros muelleri, Chlorella vulgaris, Nannochloropsis oculata and Navicula tuscula were cultured in different media and salinity $(0,5,10,15,20,25,30$ and $35 \%$ ) as follows:

Amphiprora alata: in media ASW, F/2, ESM; Chaetoceros muelleri: in media ASW, F/2, ESM, F/2 without silica; Nannochloropsis oculata: in media $\mathrm{F} / 2$, ASW, F/2 without silica, Walne; Navicula tuscula: in media ASW, ESM, F/2; and Chlorella vulgaris: in media BBM, BG11, C.

All microalgae culture bottle of 8 little were in conduction of air pumped for 24/24 and light/dark cycle of 10 hours-light intensity of 10,000 lux. Each experiment typically lasted 14 days. At 2 days intervals, each culture was removed, cells counted using Neubauer calculation chamber, then, growth curves were drawn to identify optimal condition of media and salinity for their growth. Using growth curve, the stage of maximal biomass was determined in days from 8 to 9 for all species. 


\section{Identification of fatty acids of microalgae}

The pure microalgae strains of Amphiprora alata, Chaetoceros muelleri, Chlorella vulgaris, Nannochloropsis oculata, and Navicula tuscula at the media and salinity condition as follows:

Amphiprora alata: in media ASW and salinity of 25\% ; Chaetoceros muelleri: in media ASW and salinity of $25 \%$; Nannochloropsis oculata: in media F/2 and salinity of $25 \%$; Navicula tuscula: in media ESM and salinity of 25\%; and Chlorella vulgaris: in media BBM and salinity of $25 \%$.

At stage of maximal biomass, in day 8, cultured microalgae were extracted by folowing procedure. Firtly, samples of cultured microalgaes were centrifugated at $10000 \mathrm{rpm}$ for 15 minutes and at $2^{\circ} \mathrm{C}$, then, added into extraction solution (metanol/chloroform $(1: 1) \mathrm{v} / \mathrm{v})$ and rotary evoporated to have the cells followed by lipid extraction.

Fatty acid methyl esters were obtained by dissolving the cells in mixture of metanol and sulfuric acid (with ratio of 95/5) and boiled at $80^{\circ} \mathrm{C}$ for 4 hours; and then $2 \mathrm{ml}$ of water were added. The esterified fatty acids were extracted again with $2 \mathrm{ml}$-hexan. The mixture of methyl esters of fatty acids profiles were determined by Gas Chromatography (Finnigan Trace GC, colum BPX70 (50M)) at Department of Marine Biology, Institute of Natural Products Chemistry, Vietnam Academy of Science and Technology. Fatty acids profile data were obtained by comparing retention time in relation to that of standard solution.

\section{Protein content identification of microalgae}

As identification of fatty acids of microalgae, cultured microalgaes were collected at stage of maximal biomass and then were dried. Dried microalgae samples were hydrolized in $1 \mathrm{~N}$ of $\mathrm{NaOH}$ solution for 1 hour. After that, the hydrolysis solution was diluted 5 times and centrifugated at speed of $4000 \mathrm{rpm}$ for 15 minutes. Sample solution was analysed using Bradford method with Bovine Serum Albumin (BSA) as standard solution at $595 \mathrm{~nm}$ wavelength (Ben-Amotz et. al., 1987; Nguyen Van Mui, 2001).

\section{Carbohydrate content identification of micro algae}

As identification of protein content of microalgae, cultured microalgaes were collected at stage of maximal biomass and then were dried. According to method proposed by Ben-Amotz et al. (1987), dried microalgae samples were hydrolized in $2.5 \mathrm{~N}$ $\mathrm{HCl}$ solution for 1 hour. After that, the hydrolysis solution was diluted 20 times and centrifugated at speed of $8000 \mathrm{rpm}$ for 15 minutes. Sample solution was analysed by phenol-acid sulfuric method using 5\% phenol and $96 \% \mathrm{H}_{2} \mathrm{SO}_{4}$ with glucose as standard at $490 \mathrm{~nm}$ wavelength.

\section{RESULTS AND DISCUSSION}

\section{Fatty acid component of Amphiprora alata}

Fatty acid is a carboxylic acid with a long aliphatic chain. Most naturally occurring fatty acids have an unbranched chain of an even number of carbon atoms, from 4 to 28 . Fatty acids are surfactants one water soluble endand one oil soluble end. Fatty acid is either saturated or unsaturated. Fatty acids are essential components of cell membrane of living organisms. The results of fatty acid analysis for microalgae Amphiprora alata are shown in table 1.

Table 1 shows that fatty acid content of Amphiprora alata is very diverse, from $12 \mathrm{C}$ to 24C chains. Among these, 9 saturated fatty acid make up to $44.43 \%$ and 12 unsaturated fatty acid to $52.21 \%$. Percentage of polyunsaturated fatty acid (PUFA) is $30 \%$. These fatty acids are important in forming cell membrane and have high pharmaceutical 
values. Especially, Amphiprora alata contains valuable unsaturated fatty acid such as $\mathrm{C}$ 22:6n-3 (DHA) (5.25\%) playing important role in brain and retina development and tissue regeneration; C 20:5n-3 (EPA) (9.12\%) being essential element in progastagladin synthesis; and C 20:4n-6 (AA) (7.96\%) being crucial fatty acid in bond tissue development and recover. This shows that Amphiprora alata has very high quality nutrient and can be used in aquaculture food production and human functional food production.

Table 1. Fatty acid content of Amphiprora alata

\begin{tabular}{|c|c|c|c|c|}
\hline No. & Fatty acid & Scientific name & Common name & $\begin{array}{c}\text { Percentage } \\
(\% \text { total fatty acid })\end{array}$ \\
\hline 1 & C 12:0 & Dodecanoic acid & Lauric & 0.63 \\
\hline 2 & C 14:0 & Tetradecanoic acid & Myristic & 13.26 \\
\hline 3 & C 15:0 & Pentadecanoic acid & Convolvulinolic & 1.10 \\
\hline 4 & C $15: 1 n-5$ & Pentadecenoic acid & Hormelic & 0.34 \\
\hline 5 & C 16:0 & Hexadecanoic acid & Palmitic & 14.31 \\
\hline 6 & C 16:1n-7 & 9-hexadecenoic acid & Palmitoleic & 13.15 \\
\hline 7 & C 16:1n-9 & 7-hexadecenoic acid & Ambrettolic & 4.47 \\
\hline 8 & C 17:0 & Heptadecanoic acid & Margric & 5.01 \\
\hline 9 & C $17: 1 n-7$ & Heptadecenoic acid & -- & 0.82 \\
\hline 10 & C 18:0 & Octadecanoic acid & Stearic & 4.15 \\
\hline 11 & C 18:1n-7 & 11-octadecenoic acid & Asclepic & 4.65 \\
\hline 12 & C 19:0 & Nonadecanoic acid & Isoarachidic & 0.92 \\
\hline 13 & C 18:5n-3 & Octadecapentaenoic acid & -- & 0.58 \\
\hline 14 & C 18: 4n-3 & Octadecatetraenoic acid & -- & 0.59 \\
\hline 15 & C 20:0 & Eicosanoic acid & Arachidic & 2.21 \\
\hline 16 & C 20:1n-9 & 11-eicosaenoic acid & Gondoic & 1.45 \\
\hline 17 & C $20: 4 n-6$ & $\begin{array}{c}5,8,11,14 \text {-eicosatetraenoic } \\
\text { acid }\end{array}$ & Arachidonic acid (AA) & 7.97 \\
\hline 18 & C $20: 5 n-3$ & $\begin{array}{c}5,8,11,14,17- \\
\text { eicosapentaenoic acid }\end{array}$ & Eicosapentaenoic acid (EPA) & 9.12 \\
\hline 19 & C 22:5n-6 & Docosatetraenoic acid & Docosatetraenoic acid (DPA) & 3.65 \\
\hline 20 & C 22:6n-3 & $\begin{array}{l}4,7,10,13,16,19- \\
\text { docosahexaenoic }\end{array}$ & Docosahexaenoic acid (DHA) & 5.25 \\
\hline 21 & C 24:0 & Tetracosanoic acid & Lignoceric & 2.83 \\
\hline \multicolumn{4}{|c|}{ Total saturated fatty acid (9) } & 44.43 \\
\hline \multicolumn{4}{|c|}{ Total unsaturated fatty acid (12) } & 52.21 \\
\hline
\end{tabular}

Note: symbol (--) indicates fatty acids that do not present (either unidentified or insignificant amount detected) or are not yet named

\section{Fatty acid component of Chaetoceros muelleri}

The results of fatty acid analysis for microalgae Chaetoceros muelleri are shown in table 2 .

Table 2 shows that fatty acid content of Chaetoceros muelleri is fairly diverse, including $12 \mathrm{C}$ to $24 \mathrm{C}$ chains. Among these, there are 7 saturated fatty acid making up to
$20.33 \%$ and 12 unsaturated fatty acid making up to $76.35 \%$. Saturated fatty acid counts for highest percentage $(9.52 \%)$ of $\mathrm{C} 17: 0$, and unsaturated fatty acid count for highest percentage $(24.76 \%)$ of C20:5n-3 (EPA). Percentage of polyunsaturated fatty acids of Chaetoceros muelleri is $36.63 \%$ and EPA and AA of them is of $7.84 \%$ ). Meanwhile, Chaetoceros muelleri collected form the 
Brazil contained high levels of the 18:0 $(14.38 \%)$, followed by the $14: 0(1.89 \%)$ and the 20:3 (9.69\%) (Ohse et al., 2015). It can be seen that Chaetoceros muelleri provides nutritious food source for aquaculture of mollusks and crustaceans.

Table 2. Fatty acid content of Chaetoceros muelleri

\begin{tabular}{|c|c|c|c|c|}
\hline No. & Fatty acid & Scientific name & Common name & $\begin{array}{c}\text { Percentage (\% total } \\
\text { fatty acid) }\end{array}$ \\
\hline 1 & C 14:0 & Tetradecanoic acid & Myristic & 1.91 \\
\hline 2 & C $14: 1 n-5$ & Tetrade cenoic acid & Myristoleic & 18.09 \\
\hline 3 & C 15:0 & Pentadecanoic acid & Convolvulinolic & 0.74 \\
\hline 4 & C $15: 1 n-5$ & Pentadecenoic acid & Hormelic & 0.096 \\
\hline 5 & C 16:0 & Hexadecanoic acid & Palmitic & 5.53 \\
\hline 6 & C $16: 1 n-7$ & 9-hexadecenoic acid & Palmitoleic & 15.23 \\
\hline 7 & C 16:1n-9 & 7-hexadecenoic acid & Ambrettolic & 2.20 \\
\hline 8 & C 17:0 & Heptadecanoic acid & Margric & 9.52 \\
\hline 9 & C 18:0 & Octadecanoic acid & Stearic & 1.46 \\
\hline 10 & C 18:1n-7 & 11-octadecenoic acid & Asclepic & 3.74 \\
\hline 11 & C $18: 2 n-6-t$ & $\begin{array}{c}\text { 9,12-octadecadienoic } \\
\text { acid }\end{array}$ & Linoleic & 2.70 \\
\hline 12 & C $18: 3 n-6$ & $\begin{array}{c}6,9,12 \text {-octadecatrienoic } \\
\text { acid }\end{array}$ & $\gamma$ - Linolenic acid (GLA) & 1.12 \\
\hline 13 & C $18: 4 n-3$ & Octadecatetraenoic acid & -- & 0.22 \\
\hline 14 & C 20:0 & Eicosanoic acid & Arachidic & 1.05 \\
\hline 15 & C 20:1n-7 & 13-eicosaenoic acid & Paullinic & 0.26 \\
\hline 16 & C 20:1n-9 & 11-eicosaenoic acid & Gondoic & 0.10 \\
\hline 17 & C $20: 4 n-6$ & $\begin{array}{c}5,8,11,14- \\
\text { eicosatetraenoic acid }\end{array}$ & Arachidonic acid (AA) & 7.84 \\
\hline 18 & C $20: 5 n-3$ & $\begin{array}{c}5,8,11,14,17- \\
\text { Eicosapentaenoic acid }\end{array}$ & Eicosapentaenoic acid (EPA) & 24.76 \\
\hline 19 & C 24:0 & Tetracosanoic acid & Lignoceric & 0.12 \\
\hline \multirow{2}{*}{\multicolumn{4}{|c|}{ Total saturated fatty acid (7) }} & 20.33 \\
\hline \multicolumn{3}{|c|}{ Total unsaturated fatty acid (12) } & & 76.35 \\
\hline
\end{tabular}

Note: symbol (--) indicates fatty acids that do not present (either unidentified or insignificant amount detected) or are not yet named

\section{Fatty acid content of Chlorella vulgaris}

The results of fatty acid analysis for microalgae Chlorella vulgaris are shown in table 3.

As shown in table 3, the fatty acid content of microalgae Chlorella vulgaris is not as diverse as previously analyzed microalgae. There are 11 fatty acids in Chlorella vulgaris comprising of 5 saturated fatty acids (39.55\%) and 6 unsaturated fatty acids $(59.24 \%)$. Chlorella vulgaris does not contain AA, EPA, DHA, DPA but two double-bond unsaturated fatty acids which are C18:2n-6-t (LA) and C18:3n-3 make up to $25.88 \%$. These are two important fatty acids for growth, development of organisms that cannot be synthesized directly by human and animals. These two fatty acids play crucial roles in brain development. LA content is 
indicator to evaluate bio-value of fat. Chlorella vulgaris collected form the Brazil contained high levels of the 18:3d (22.17\%), followed by the 16:0 (21.17\%), $18: 0$ $(15.47 \%)$, and the $18: 1 \mathrm{c}(13.46 \%)$ (Ohse et al., 2015). Hence, identifying exact culture time to get the highest content of fatty acids for Chlorella vulgaris and combining
Chlorella vulgaris with other microalgae will help to produce high nutritious food sources for aquaculture.

Fatty acid content of Nannochloropsis oculata

Fatty acid content of Nannochloropsis oculata is quite rich (Table 4).

Table 3. Fatty acid content of Chlorella vulgaris

\begin{tabular}{|c|c|c|c|c|}
\hline No. & Fatty acid & Scientific name & Common name & $\begin{array}{c}\text { Percentage } \\
(\% \text { total fatty acid) }\end{array}$ \\
\hline 1 & C 14:0 & Tetradecanoic acid & Myristic & 1.53 \\
\hline 2 & C 16:0 & Hexadecanoic acid & Palmitic & 27.43 \\
\hline 3 & C $16: 1 n-7$ & 9-hexadecenoic acid & Palmitoleic & 5.15 \\
\hline 4 & C $16: 1 n-9$ & 7-hexadecenoic acid & Ambrettolic & 1.2 \\
\hline 5 & C 17:0 & Heptadecanoic acid & Margric & 2.69 \\
\hline 6 & C $17: 1 n-7$ & Heptadecenoic acid & -- & 6.15 \\
\hline 7 & C 18:0 & Octadecanoic acid & Stearic & 2.91 \\
\hline 8 & C 18:1n-9 & 9-octadecenoic acid & Oleic & 20.06 \\
\hline 9 & C $18: 2 n-6-t$ & 9,12-octadecadienoic acid & Linoleic acid(LA) & 8.42 \\
\hline 10 & C $18: 3 n-3$ & 9,12,15-octadecatrienoic acid & Anpha-Linoleic acid(LNA) & 17.46 \\
\hline 11 & C 20:0 & Eicosanoic acid & Arachidic & 4.98 \\
\hline \multicolumn{4}{|c|}{ Total saturated fatty acid (5) } & 39.55 \\
\hline \multicolumn{4}{|c|}{ Total unsaturated fatty acid (6) } & 59.24 \\
\hline
\end{tabular}

Note: symbol (--) indicates fatty acids that do not present (either unidentified or insignificant amount detected) or are not yet named

Table 4 shows that fatty acid content of Nannochloropsis oculata is quite diverse. $N$. oculata has more than 30 fatty acids, among those are 6 saturated fatty acids $(25.6 \%)$ and 18unsaturated fatty acids (71.7\%). EPA (C20:5n-3) has the highest percentage $(26.7 \%)$. This is the characteristic of the genus Nannochloropsis. Fatty acid palmitic (16:0) and fatty acid palmitoleic (16:1n-7) occupy $21.3 \%$ and $14.4 \%$ accordingly. Especially, acid linoleic (LA) and acid $\alpha$-linoleic also have quite high percentages, $7.6 \%$ and $5.8 \%$. The result shows that total of fatty acid group (n-3) occupy $36.3 \%$ of total fatty acid content. These are unsaturated fatty acids that are very important in enhancing active ability of brain cells. Moreover, total percentage of fatty acid group (n-6) which is important to child development is $8.7 \%$. Ohse et al., 2015 showed that Nannochloropsis oculata in Brazile contained quite high percentage of fatty acids of 16:0 and 16:1 (33.17\% and 30.96\%), which are much higher than those of Nannochloropsis oculata in this study. Ronquillo et al. (2012) indicated that the best diet in culturing European oyster juveniles was the mixture of Nannochloropsis oculata and Pavlova lutheri by providing better growth rates and higher levels of PUFAs. In conclusion, microalgae Nannochloropsis oculata has very diverse and rich fatty acid content comprising high percentage of important fatty acids. This has very valuable application to aquaculture and daily use. 
Table 4. Fatty acid content of Nannochloropsis oculata

\begin{tabular}{|c|c|c|c|c|}
\hline No. & Fatty acid & Scientific name & Common name & $\begin{array}{l}\text { Percentage (\% } \\
\text { total fatty acid) }\end{array}$ \\
\hline 1 & C 12:0 & Dodecanoic acid & Lauric & 0.2 \\
\hline 2 & C 14:0 & Tetradecanoic acid & Myristic & 3.6 \\
\hline 3 & C 16:0 & Hexadecanoic acid & Palmitic & 21.3 \\
\hline 4 & C 16:1n-7 & 9-hexadecenoic acid & Palmitoleic & 14.4 \\
\hline 5 & C 16:2n & -- & -- & 1.2 \\
\hline 6 & C $16: 3 n-6$ & hexadecatrienoic acid & -- & 0.2 \\
\hline 7 & C $16: 3 n-3$ & 7,10,13-hexadecatrienoic acid & -- & 3.7 \\
\hline 8 & C 18:0 & Octadecanoic acid & Stearic & 0.3 \\
\hline 9 & C $18: 1 n$ & Cis 9 oleic acid & -- & 7.6 \\
\hline 10 & C $18: 2 n-6$ & 9,12-Octadecadienoic acid & Linoleic acid(LA) & 7.6 \\
\hline 11 & C $18: 3 n-6$ & 6,9,12-Octadecatrienoic acid & gamma-Linolenic Acid & 0.3 \\
\hline 12 & C $18: 3 n-3$ & $9,12,15$-octadecatrienoic acid & $\begin{array}{c}\text { Anpha-Linoleic Acid } \\
\text { (LNA) }\end{array}$ & 5.8 \\
\hline 14 & C 20:0 & Eicosanoic acid & Arachidic & 0.1 \\
\hline 15 & C 20:1n & 11-eicosenoic acid & -- & 0,2 \\
\hline 16 & C 20:2n-9 & 8,11-cis-eicosadienoic acid & -- & 0,1 \\
\hline 17 & C 20:2n-6 & 11,14-ecosadienoic acid & Eicosadienoic Acid & 0.1 \\
\hline 18 & C 20:3n-9 & 5,8,11-eicosatrienoic acid & Mead Acid & 0.1 \\
\hline 19 & C 20:3n-6 & $8,11,14$-eicosatrienoic acid & Dihomo-g -Linolenic Acid & 0.2 \\
\hline 20 & C $20: 4 n-6$ & $\begin{array}{c}\text { 5,8,11,14-Eicosatetraenoic } \\
\text { acid }\end{array}$ & Arachidonic Acid (AA) & 3.0 \\
\hline 23 & C $20: 5 n-3$ & $\begin{array}{c}5,8,11,14,17- \\
\text { Eicosapentaenoic acid }\end{array}$ & Timnodonic Acid (EPA) & 26.7 \\
\hline 24 & C 22:0 & -- & Behenic acid & 0.1 \\
\hline 25 & C 22:1 & 13-docosenoic acid & -- & 0.1 \\
\hline 27 & C $22: 4 n-6$ & $\begin{array}{c}\text { 7,10-13-16-Ocosatetraenoic } \\
\text { acid }\end{array}$ & Adrenic Acid & 0.3 \\
\hline 30 & C $22: 6 n-3$ & $\begin{array}{c}4,7,10,13,16,19- \\
\text { Docosahexaenoic acid }\end{array}$ & $\begin{array}{c}\text { Docosahexaenoic Acid } \\
\text { (DHA) }\end{array}$ & 0.1 \\
\hline 31 & & & other Acid & 2.8 \\
\hline \multicolumn{4}{|c|}{ Total saturated fatty acid (6) } & 25.6 \\
\hline \multicolumn{4}{|c|}{ Total unsaturated fatty acid (18) } & 71.7 \\
\hline
\end{tabular}

Note: symbol (--) indicates fatty acids that do not present (either unidentified or insignificant amount detected) or are not yet named.

\section{Fatty acid content of Navicula tuscula}

The results of fatty acid analysis for microalgae Navicula tuscual are shown in table 5 .

Microalgae Navicula tuscula has 7 saturated fatty acids (69.761\%) and 10 unsaturated fatty acid (29.597\%). Content of unsaturated fatty acid of Navicula tuscula is lowest among all microalgae studied in this research (Table 5). Fatty acid having highest percentage is saturated acid C16:0 (52.57\%). Besides, percentages of $\omega 3$ and $\omega 6$ fatty acid groups are also quite low but the composition of $\omega 6$ fatty acid group is very diverse (C 20:4n-6, C 22:4n-6, C 18:2n-6, C 18:3n-6). However, Navicula tuscula is large microalgae and appropriate to be used as food for parental bodies in aquaculture. The combination of Navicula tuscula with other microalgae to produce nutritious supplement 
for aquaculture objects including both larvae and parental bodies are very useful. This is simlar to the resuls of fatty acid profiles of Navicula tuscula collected from Giao Thuy in 2010, which indicated high concentration of $16: 0,16: 1 \mathrm{n}-7$ and $14: 0$ (more than $60 \%$ of total fatty acids) (Hoa et al., 2010).

From results shown in tables $1-5$, it is observed that the fatty acid contents of five studied microalgae are quite diverse. Most of microalgae have high percentage of unsaturated fatty acid except for the case of Navicula tuscula having higher percentage of saturated acid comparing to unsaturated one. This means studied microalgae have good nutritious quality. In general, nutritious value of fatty acid of diatoms is usually higher than that of green algae and the ratio of saturated acid and unsaturated acid varies for different microalgae. Nannochloropsis oculata is onecell microalgae with diverse fatty acid content and can be good nutrition source for aquaculture. Therefore, a sophisticated combination of these microalgae as food supplied for different stages of development of aquaculture subjects such as snout otter clam, bivalves, crustaceans, etc. can yield high productivity and quality.

\section{Protein contents of studied microalage}

Protein content is one of the essential factors to evaluate nutritious value of microalgae. The results of protein content analysis are compiled in Fig. 1.

Table 5. Fatty acid content of Navicula tuscula

\begin{tabular}{|c|c|c|c|c|}
\hline No. & Fatty acid & Scientific name & Common name & \begin{tabular}{|c} 
Percentage (\% total \\
fatty acid)
\end{tabular} \\
\hline 1 & $\mathrm{C} 4: 0$ & Butyric acid & -- & 1.17 \\
\hline 2 & C 10:0 & Decanoic acid & -- & 0.33 \\
\hline 3 & C 14:0 & Tetradecanoic acid & Myristic & 9.69 \\
\hline 4 & C $14: 1 n-5$ & Tetrade cenoic acid & Myristoleic & 0.80 \\
\hline 5 & C $15: 1 n-5$ & Pentadecenoic acid & Hormelic & 0.70 \\
\hline 6 & C 16:0 & Hexadecanoic acid & Palmitic & 52.56 \\
\hline 7 & C $16: 1 n-7$ & 9-hexadecenoic acid & Palmitoleic & 13.67 \\
\hline 8 & C 17:0 & Heptadecanoic acid & Margric & 1.20 \\
\hline 9 & C $17: 1 n-7$ & Heptadecenoic acid & -- & 1.49 \\
\hline 10 & C 18:0 & Octadecanoic acid & Stearic & 3.77 \\
\hline 11 & C 18:1n-7 & 11-octadecenoic acid & Asclepic & 8.62 \\
\hline 12 & C $18: 2 n-6$ & 9,12-Octadecadienoic acid & Linoleic acid(LA) & 1.27 \\
\hline 13 & C $18: 3 n-6$ & 6,9,12-Octadecatrienoic Acid & gamma -linolenic acid & 0.35 \\
\hline 14 & C $18: 5 n-3$ & Octadecapentaenoic acid & -- & 1.56 \\
\hline 15 & C 20:4n-6 & 5,8,11,14-eicosatetraenoic acid & Arachidonic acid (AA) & 0.76 \\
\hline 16 & C 22:0 & -- & Behenic acid & 1.04 \\
\hline 17 & C $22: 4 n-6$ & 7,10-13-16-Ocosatetraenoic acid & Adrenic acid & 0.34 \\
\hline \multicolumn{4}{|c|}{ Total saturated fatty acid (7) } & 69.76 \\
\hline \multicolumn{4}{|c|}{ Total unsaturated fatty acid (10) } & 29.56 \\
\hline
\end{tabular}

Note: symbol (--) indicates fatty acids that do not present (either unidentified or insignificant amount detected) or are not yet named

Protein content is highest in Amphiprora alata species, followed by Chaetoceros muelleri, Nannochloropsis oculata, Navicula tuscula and lowest in Chlorella vulgaris
(Fig. 2). It is also observed that microalgae with high fatty acid content has high protein content giving it high nutritious value. All studied microalgae have quite similar protein 
content in the range of $5.08 \%$ to $8.01 \%$. Protein is an important organic compound to all activities of living organisms such as catalysis, transport, protection, storage, harmonization, etc. Therefore, addition of protein in food source is very necessary. Moreover, to produce food source with enough content of amine acid used in aquaculture, a combination of all abovementioned microalgae should be considered.

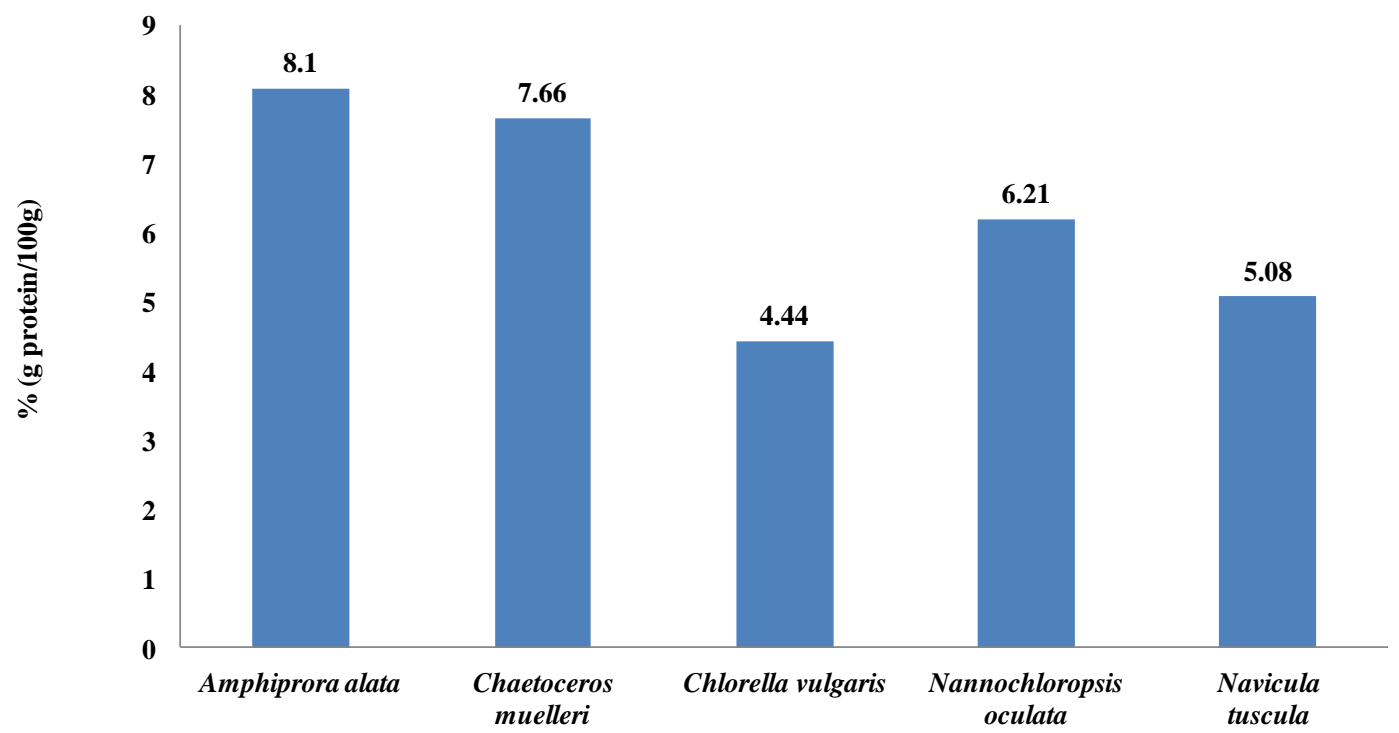

Figure 1. Protein content (g protein/100g dry weight) of studied microalgae

\section{Carbohydrate contents of studied microalage}

Carbohydrate (sugar, starch and fibre) is also named glucid. Carbohydrate plays important role in providing energy for organism bodies. Analysis results of carbohydrate content are shown in Fig. 2.

Nannochloropsis oculata species has the highest carbohydrate content, followed by Chaetoceros muelleri, Chlorella vulgaris, Amphiprora alata and Navicula tuscula. The differences in carbohydrate content of studied microalgae are bigger than those in protein content (e.g. carbohydrate content in Nannochloropsis oculata is double that in Navicula tuscula). Compiling the results of protein contents and fatty acid contents shows that Nannochloropsis oculata has the highest nutritious value. However, it is not advisable to use only this species as food supplement. The better way is to combine with other species to produce the optimal food source.

Analysis results show that fatty acid content, protein content and carbohydrate content are quite diverse and typical for each microalgae species. The combination of all these microalgae will produce quite sufficient nutrient with high percentage of double-bond unsaturated fatty acid (DHA, EPA) as well as provide plentiful protein and carbohydrate amount for important metabolisms of organisms. Effective combination of these 5 microalgae with diversity in size will create high nutrient food sources for coastal quaculture. 


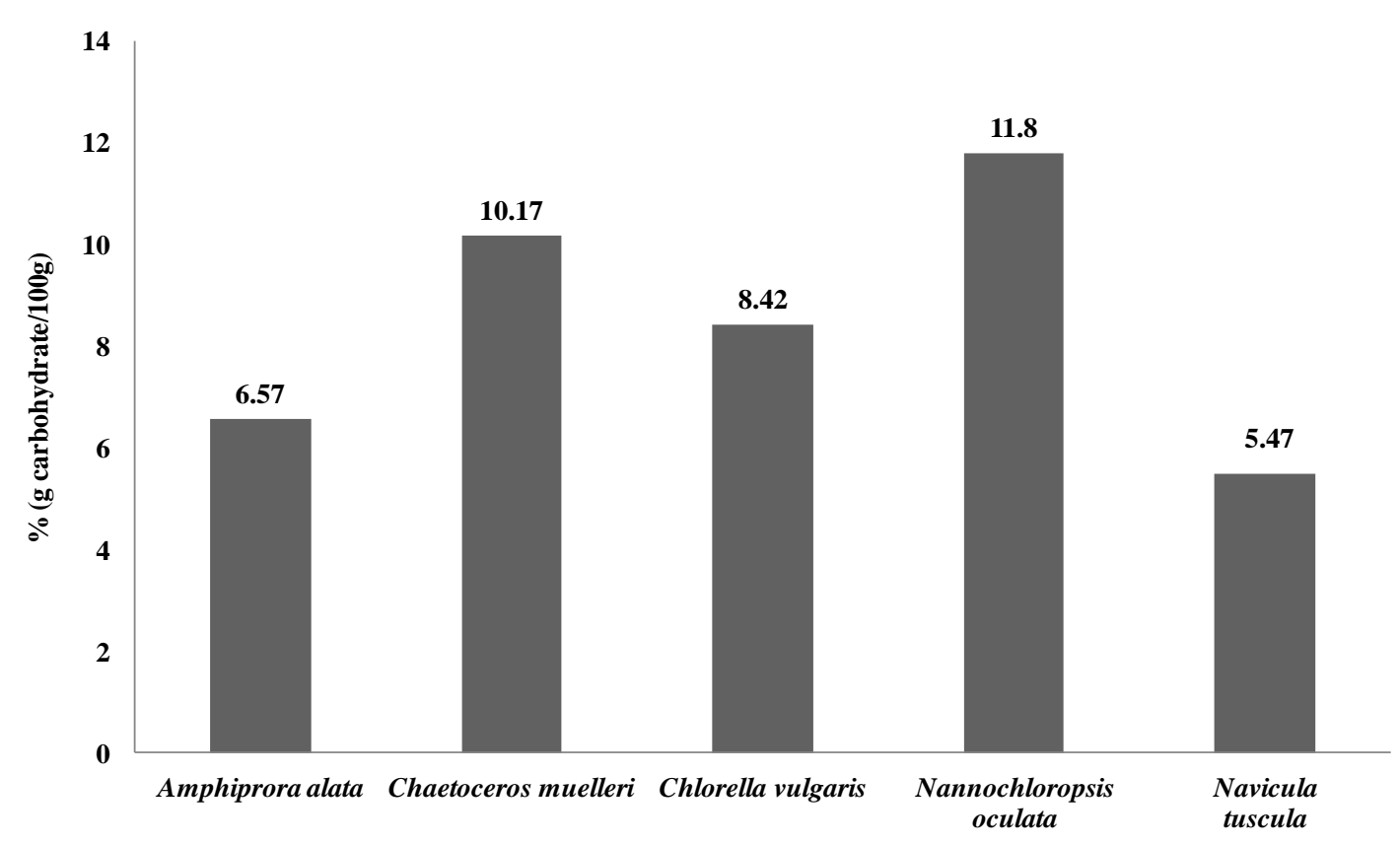

Figure 2. Carbohydrate content (g carbohydrate/100g dry weight) of microalgae

\section{CONCLUSION}

Of the total five studied microalgae rich in nutrient. Nannochloropsis oculata has the most diverse fatty acid content (24 types of fatty acids with $71.7 \%$ of unsaturated fatty acid). Navicula tuscula has the lowest fatty acid content (17 types of fatty acid with $29.6 \%$ of unsaturated fatty acid). Amphiprora alata is very richest in protein $(8.1 \mathrm{~g} / 100 \mathrm{~g}$ dry weight) and Chlorella vulgaris has the lowest protein content $(4.44 \mathrm{~g} / 100 \mathrm{~g}$ dry weight). Nannochloropsis oculata has the highest carbohydrate content $(11.8 \mathrm{~g} / 100 \mathrm{~g}$ dry weight) and Navicula tuscula has the lowest $(5.47 \mathrm{~g} / 100 \mathrm{~g}$ dry weight). From study results, it is suggested that pilot experiment should be conducted using microalage with different compositions in food portion of different aquaculture objects, in order to improve productivity and maximize the use of valuable nutritious sources from isolated microalgae in coastal mangrove.

\section{REFERENCES}

Akihiko Shirota, 1996. The plankton of South Vietnam fresh and marine plankton, Oversea technical cooperation Agency Japan.

Truong Ngoc An, 1993. Classification of Vietnam marine diatoms, Science and Technology Publisher, Ha Noi, 256p.

Ben-Amotz, Fishier R., Schneller A., 1987. Marine Biology, 95: 31-36.

Jesse D. Ronquillo, Jamie Fraser, Audrie-Jo McConkey, 2012. Effect of mixed microalgal diets on growth and polyunsaturated fatty acid profile of European oyster (Ostrea edulis) juveniles. Aquaculture, 360-361: 64-68.

Le Thi Phuong Hoa, Nguyen Thi Hoai Ha, Dang Ngoc Quang, Nguyen Hoang Tri, 2010a. Fatty acid profiles of mangrove microalgae and their potential use as food, Journal of Science and Technology, 48(2A): 609-614. 
Le Thi Phuong Hoa, Nguyen Thi Hoai Ha, Pham Thi Bich Dao, Nguyen Ngoc Tuyen, 2010b. Biological properties and biomass culture of Chaertoceros muelleri from Giao Thuy mangrove for use in aquaculture", J. Sci. HNUE, 55(6): 141-148.

Liang Shizhong, LiangXueming, Liu Feng, ChenZijian Chen, 2004. Current microalgal health food $\mathrm{R} \& \mathrm{D}$ activities in China. Hydrobiologia, 512(1-3): 45-48.

Makoto Shirai, Katsumi Matumaru, Akio Ohotake, Yoshichika Takamura, Tokujiro Aida, Masayasu Nakano, 1989. Development of a Solid Medium for Growth and Isolation of Axenic Microcystis Strains (Cyanobacteria). Applied and Environmental microbiology, 55(10): 2569-2571.

Mohammad Malakootian, Behnam Hatami, Shidwash Dowlatshahi, Ahmad Rajabizadeh, 2015. Optimization of culture media for lipid production by Nannochloropsis oculata for Biodiesel production. Environmental Health Engineering and Management Journal, 2(3): 141-147.

Nguyen Van Mui, 2001. Biochemistry Practical, Hanoi National University Publisher, p.89.

Muller-Feuga A., Robert R., Cahu C., Robin J., Divanach P., 2003. Chapter 7. Uses of Microalgae in Aquaculture. In: Live Feeds in Marine Aquaculture (Edited by Josianne G. Støttrup, Lesley A. McEvoy).
Blackwell Science Ltd. ISBN 0-63205495-6.

Parrish C. C., Wells J. S., Yang Z., Dabinett P., 1998. Growth and lipid composition of scallop juveniles, Placopecten magellanicus, fed the flagellate Isochrysis galbana with varying lipid composition and the diatom Chaetoceros muelleri. Marine Biology, 133(3): 461-471.

FAO, 2000. The State of Food and Agriculture, Rome, 2000. ISBN 92-5104400-7.

Silvana Ohse, Roberto Bianchini Derner, Renata Ávila Ozório, Rafaela Gordo Corrêa, Eliana Badiale Furlong, Paulo Cesar Roberto Cunha, 2015. Lipid content and fatty acid profiles in ten species of microalgae. IDESIA (Chile) Diciembre 2014/Enero-Febrero, 33(1): 93-101.

Le Xuan Tuan, Mai Sy Tuan, 2005. Research on quality and content of Phyplankton in mangrove at Giao Lac Commune, Giao Thuy District, Nam Dinh Province. Proceedings of Conference of Environment and sustainable development. Science and Technology Publisher, 450-461.

Le Xuan Tuan, Mai Sy Tuan, Le Thi Phuong and Nguyen Thi Thu Hoa, 2008. Study on the ability of Platymonas sp. And Nanochloropsis oculata micro-algae to reduce shrimp pond water pollution in Giao Thuy district, Nam Dinh province. Journal of Science of HNUE, 53(7): 83-89. 
